\title{
The Map Specialcharte von Livland: Georg Friedrich Parrot's Agenda or a New Perspective on Livland ${ }^{1}$
}

\author{
Martin Jeske \\ Department of History, \\ University of Basel \\ Hirschgaesslein 21, \\ Basel CH-4051, Switzerland \\ E-mail: martin.jeske@unibas.ch
}

\begin{abstract}
In 1839, the topographic map Specialcharte von Livland was published by the Livonian Charitable and Economic Society (Livländische Gemeinnützige und Ökonomische Sozietät). In comparison to the previous topographic map of Livonia, the main topics of the new map were agriculture and trade-key sources of Livland's economy. The idea of creating such a map reflects the thinking of early nineteenth-century Livland when science and methodological theory would determine the future measures to achieve prosperity for all. Georg Friedrich Parrot, the first secretary of the Livonian Charitable and Economic Society and later professor and Prorector of the University of Dorpat, was one of the central figures who represented Physiocratic and Cameralistic thinking and action. The map depicts Parrot's agenda as a new perspective on Livland.
\end{abstract}

Keywords: agriculture and trade, Livonian Charitable and Economic Society, Parrot, Physiocratic and Cameralistic ideas, topographic map, University of Dorpat

1 I am grateful to the Swiss National Science Foundation for financing the research project 'Mapping an Empire. Territorialization, Cartography and Scientific Transfer in Tsarist Russia (1797-1919)'. 


\section{Introduction}

While studying the two and a half square meters wide topographic map on six sheets, we can see the precisely drawn ground covers of the whole territory of Livland. The cartographic picture published in 1839 shows the entire area in such detail that had not been seen thus far. This map counts as one of the first practical results of the engagement of several enlightened men who were interested in shaping the province based on rational and scientific principles. It is a fascinating historical source which on the one hand shows how the contemporaries perceived their environment cartographically and, on the other hand, the map's creation history offers an illuminating insight into the networks and influences of figures and institutions. Many people were involved in the making of this map-first and foremost, the surveyor and mapmaker Carl Gottlieb Rücker (1778-1856), who was responsible for topographic surveys, compiling and drawing of the map, and who lent his family name to the widespread short title Rücker'sche Karte.

In the early 19th century, topographic maps were not easy to make. Mapmaking was extremely expensive and required enormous amount of professional knowledge. In this context it is revealing to study the conditions which made scientific developments and exchange possible and improved land surveying and mapping in Livland. This aspect leads us to the question of the sponsor's motives and how advances in cartography were used. Such a perspective may allow us to overcome an overly positivistic picture of scientific development and get a wider perspective of the leading ideas.

My research into the purpose and creation of the map led me several times to the person of Georg Friedrich Parrot (1767-1852). The main focus of the present paper is the extent to which Parrot influenced the development of the map. To answer this question, I will first give a short description of the map and its history. ${ }^{2}$ Second, I will focus on Parrot's thoughts as a manager of Livland's economy and science. Finally, I will look at the fruits of Parrot's ideas when two of his students became the scientific supervisors responsible for the creation of the map.

2 The history of the map's compilation was partly described in 1910. The first publication about the history of the map's compilation was carried out by the Estonian geographer and local historian Endel Varep (1957). 


\section{The map}

The Specialcharte von Livland shows the territory of Livland without its island Oesel and the neighboring guberniyas Estland and Kurland, St. Petersburg, Pskov, and Vitebsk. Livland is mapped at a middle scale of roughly 1:185,000 on six sheets. ${ }^{3}$ The first edition of the map is a copperplate print on paper without any further coloration. ${ }^{4}$ Using Latin letters, the language of the map's title, legend and toponymy is German.

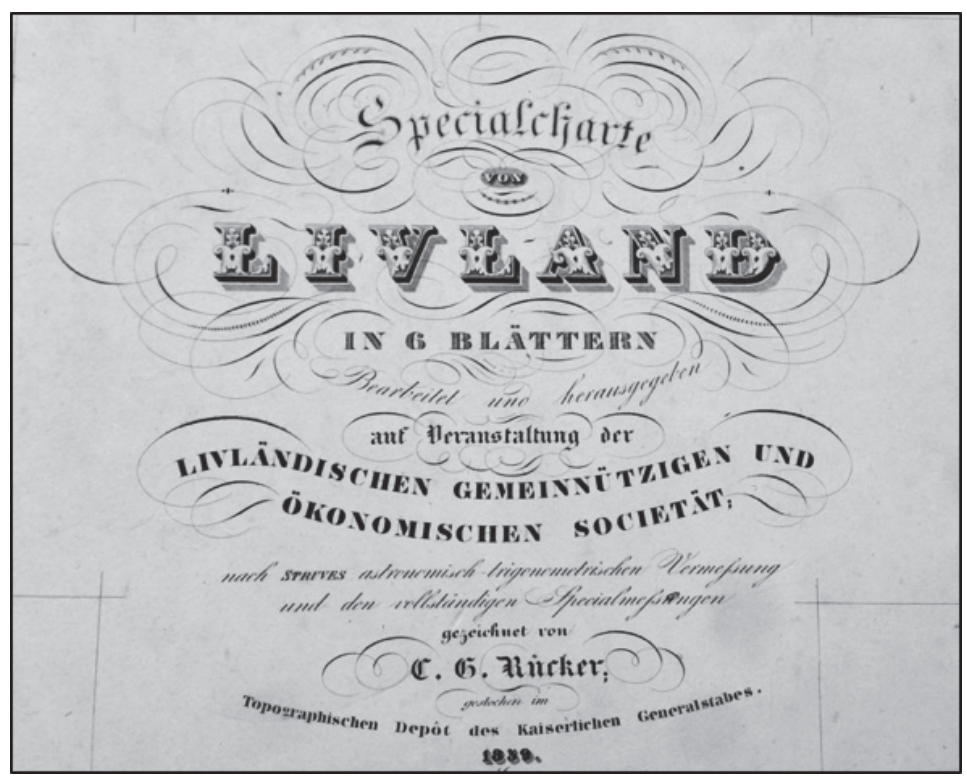

Figure 1. Downscaled cartouche on Sheet VI. Map Department Berlin State Library:

Prussian Cultural Heritage, Kart. Q 16236

The cartouche (Fig. 1) gives the German title of the map and various additional information, such as the name of the sponsor and responsible institutionthe Livonian Charitable and Economic Society (Livländische Gemeinnützige und Ökonomische Sozietät); the survey essentials-the trigonometrical and astronomical surveying by the astronomer Friedrich Georg Wilhelm Struve (1793-1864); the name of the responsible cartographer-Carl Gottlieb Rücker;

3 One centimeter on the map equals to 1,850 meters in nature.

4 The map's second edition (exact date unknown) was printed after 1889, when railroad lines and coloration of administrative borders were added. The ground covers, etc. remained unchanged. The map was available at least until 1908. 
as well as the publishing house- the military topographic depot of the Russian general staff; and the year of publication-1839.

At that time the term Specialcharte (or Spezialkarte) was already established in Europe. It labelled maps which were a compilation of reduced and copied large-scale maps. This kind of topographic map contained many symbols for a wide range of purposes (Kretschmer et al., 1986, p. 762). The Specialcharte von Livland has 46 symbols for different types of ground covers, waters, transport routes, towns, villages, manor houses, churches, ruins, mills, manufactures, administrative borders, etc. The characteristics of the used large-scale estate maps limit the orography. Especially twelve symbols for ground covers and nine symbols for trade dominate the map's content. ${ }^{5}$ The high range of their differentiation indicates that agriculture and trade are the central topics on the map. On the new map, both cultivated land and raw land were merged into one image of Livland's entire land cover for the first time.

In the 1850s, it was calculated that only 55 percent of Livland's whole land cover was cultivated land, while 45 percent was wasted raw land. There was even more swampland (17 percent) than arable land (11 percent). As a comparison-in Prussia or England arable land made up 46 and 78 percent, respectively (Hehn, 1858, pp. 32-35, 111). Already at the beginning the 19th century, the designated purpose in Livland was to expand cultivated land and accelerate trade in agrarian products (Friebe, 1802, p. 3).

A comparison with the previous huge map project from the 1790s, Atlas von Liefland (see Fig. 3; Mellin, 1798), reveals an enormous difference in the cartographic representation of Livland by Count Ludwig August von Mellin (1754-1835), a former quartermaster of the Russian Army. Whereas the military strategic and tactical descriptions of the (mostly fanciful) orography, such as woodlands, swamplands and historical battlefields were mapped, the arable land, meadows and bushes as the basis of agriculture and also different manufactures, factories and mills as places of trade were sparsely or not at all addressed. The comparative perspective reveals a new perception of Livland's territory from the aspect of agriculture and trade, which were the most important economic sectors of the province.

5 Symbols for the ground cover: field, scrubland, hay meadow, hardwood land on quagmire, conifer woodland, hardwood land on dry soil, heather and conifer woodland, mixed forest on dry soil, small shrubbery as pasture, mire with shrubbery, sand desert. Symbols for trade: water mill, paper mill, timber mill, copper hammer mill, windmill, manufactory, glass factory, brick factory, tavern. 


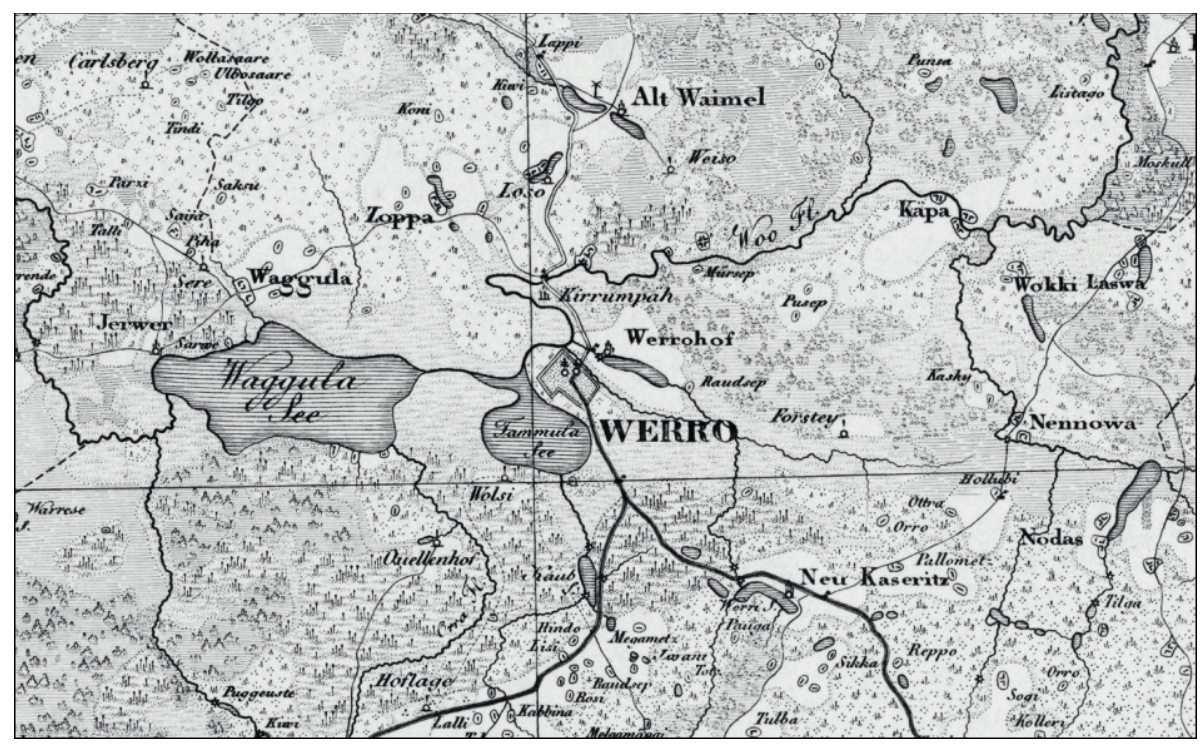

Figure 2. Downscaled extract from Sheet II of the map Specialcharte von Livland

(1839) shows the town Werro and the surrounding landscape with different ground covers, waters, villages, manors, mills and streets. Map Department Berlin State Library: Prussian Cultural Heritage, Kart. Q 16236

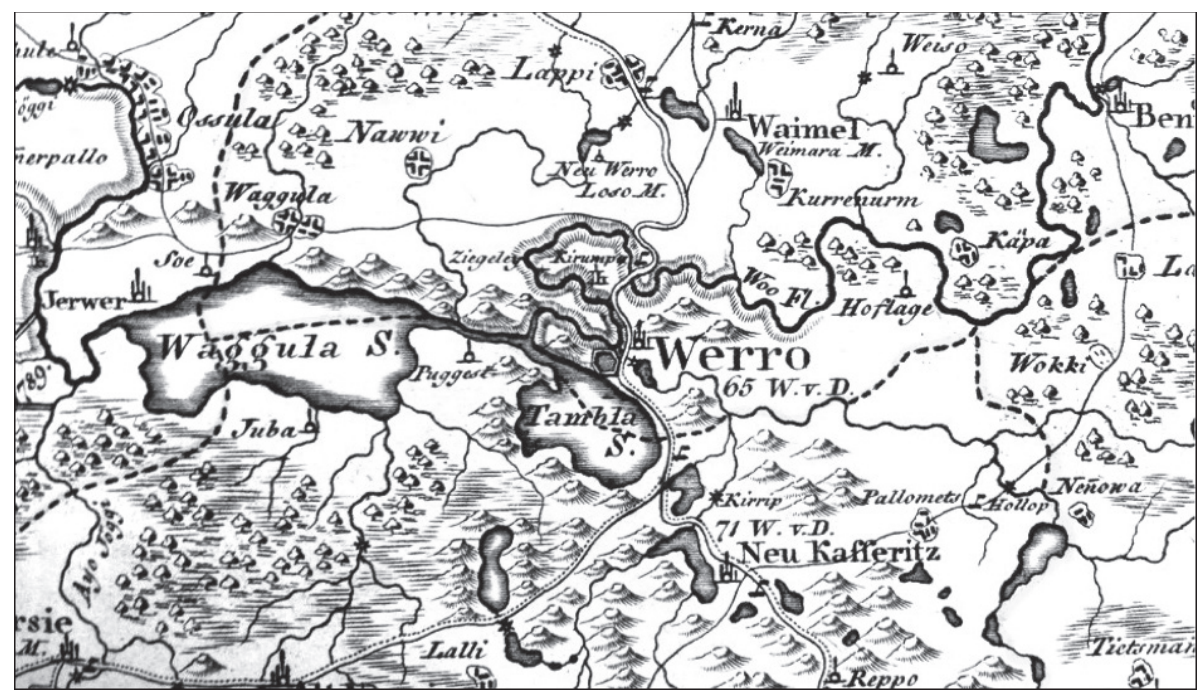

Figure 3. Downscaled extract from Sheet 5 (1798) of the Atlas von Liefland. Map

Department Berlin State Library: Prussian Cultural Heritage, Kart. Q $15663 a$ 
As presented to date, the development history of Specialcharte von Livland began in 1816 when the mineralogist Otto Moritz Ludwig von Engelhardt's (1779-1842) proposal for a new map was accepted by the Livonian Charitable and Economic Society. The society immediately instructed astronomer Struve to carry out astronomical and trigonometrical surveys for the purpose of compiling the map on a mathematical skeleton. However, an entire topographic survey of Livland was not planned. Instead, private estate maps gathered between 1809 and 1823 during the agrarian reform (on the way to the landless abolition of serfdom in Livland in 1819) were used. After Struve had finished his skeletal map, Rücker had to merge about two thousand estate maps into one consistent drawing. For that purpose, Parrot constructed an instrument called panthograph for downscaling and copying the estate maps (Parrot, 1831). The compilation and drawing, the copper engraving and printing took altogether twenty years until the map was finally published in 1839 (Numers, 1910; Varep, 1957).

\section{Parrot's agenda}

If the finished map was the realization of a specific idea, it is worth asking how this idea emerged. Engelhardt's proposal in 1816 to create a new map of Livland was definitely not an idée fixe. Obviously, Parrot's ideas helped him to carry out his own research project. Parrot was certainly not the only agent striving for the improvement of Livland's economy along Physiocratic and Cameralistic principles, but his key positions both as a promoter of rational agriculture and also economic and scientific education in Livonia allowed him to exert significant influence on the local development.

In 1796, Parrot was elected the first secretary of the Livonian Charitable and Economic Society shortly after he had anonymously published a paper about his agenda (Recke \& Napiersky, 1831, pp. 365-367). In this position, he formulated the main objective of the Livonian Charitable and Economic Society-to bring agrarian and industrial prosperity and wealth to Livland, whereas methodological theory would determine the future measures (Anonymous, 1795, pp. 31, 79-80). Looking at the model of the Royal Society of Agriculture, established in London in 1753, advances in agriculture should be achieved on the basis of science, for instance husbandry, beekeeping, peat land management, manufactures and trade, construction of roads, etc. (Blum, 1858, p. 200; Engelhardt \& Neuschäffer, 1983, pp. 11, 25). 
In 1800, Parrot left the society as he was appointed professor of theoretical and experimental physics at the later University of Dorpat. In the context of the expected reopening of the university, he suggested that the Livonian Charitable and Economic Society be moved from Riga to Dorpat, where it would benefit from the proximity of a new centre of research (Engelhardt $\&$ Neuschäffer, 1983, p. 40).

When the university was finally opened in 1802, Parrot held a speech about how knowledge of nature influences human culture. He argued that a rational perception of nature furthered the Enlightenment and encouraged prosperity for all. However, only by studying nature a rationalization of farmers' and craftsmen's production could be achieved (Parrot, 1802, p. 51). Following this combined Physiocratic and Cameralistic conviction, Parrot as the university's prorector and professor of physics (or natural studies) educated and supported his students as future public servants.

\section{The fruits of Parrot's agenda}

Two of Parrot's students—Engelhardt and Struve—supervised the making of the map, which was to provide a basis for the improvement of Livland's economy (Löwis, [1839?]). Both became public servants in the spirit of Parrot's agenda.

Although Engelhardt studied physics and chemistry in Dorpat from 1803 to 1805, we know very little about his relationship with Parrot. His studies at the Freiberg Mining Academy in Saxony between 1805 and 1808 probably had a crucial impact on his later profession as a mineralogist. In Freiberg he became a student of the influential mineralogist Abraham Gottlob Werner (1749-1817), who participated in the geognostic mapping of Saxony. After Engelhardt's return to Dorpat he was eventually involved in a mineralogical exploration of Livland between 1815 and 1817 (Recke \& Napiersky, 1827, pp. 506-509; Levitskii, 1902, pp. 201-205; Gümbel, 1897, pp. 33-39). While carrying out this research, he made the proposal for a new map of Livland at a meeting of the Livonian Charitable and Economic Society of which he was an exclusive member (Numers, 1910, p. 72). However, his proposal cannot be found in the National Archives of Estonia. ${ }^{6}$ Therefore we

6 The map's concept titled Einige Gedanken die Anfertigung eines Atlasses Livlands betreffend (1819), held in the National Archives of Estonia in Tartu (EAA, f 1185, n 1, s 48), was certainly not written by Engelhardt. The barely legible comments on the paper's title page indicate that he was not the author. Instead, the authorship is attributed to Friedrich David Jaquet, a private tutor in the noble family of von Liphardt. To the present just very little is known about him. 
do not know exactly what he suggested. Certainly his purpose was to have a precise topographic map of Livland as a basis for mapping the results of natural historical (including geognostic) exploration-obviously much the same that had been done in Saxony and elsewhere for Cameralistic purposes. For an adequate rationalization of Livland's agricultural conditions such a depiction would have been of crucial impact. ${ }^{7}$ The different bottomset beds resulted in different water conditions as well as different soil fertility (Hehn, 1858, p. 40).

Unlike Engelhardt, who was an offspring of a Baltic-German aristocratic family, philologist Struve was encouraged by Parrot to begin studies in mathematics and astronomy. With his support, Struve, a former refugee, received a double scholarship from the University of Dorpat before he became an associate professor and astronomer of the university. After he was sent to meet German astronomers, who were leading several land surveys at that time, he carried out the first astronomical-trigonometrical survey of Livland from 1816 to 1819 (Beise, 1852, pp. 71-72). This was one of the first instances of cooperation between the neighboring university and the Livonian Charitable and Economic Society. The important innovation aspect of such a survey enabled creating the most precise topographic map of Livland thus far. Only with such a mathematical skeleton it was possible to assemble a great amount of large-scale estate maps into one consistent map.

This topographic map not only allowed depicting geognostic results but also collecting statistics, as suggested by Karl Ludwig Blum (1796-1869), professor of geography and statistics at the University of Dorpat. It became possible to determine precise areas of ground covers, accessibility of places, or the extension of manufactures or mills (Blum, 1838 , pp. 88-100). The cartographic depiction of economically related objects enabled the improvement of Livland's agriculture and trade on a scientific basis.

Later, Engelhardt supported the author of the paper (Rathlef, 1852). 


\section{Conclusion}

The Specialcharte von Livland provided a new perspective on Livland. Instead of a military perception of the territory as represented by the previous topographic map, Atlas von Liefland, the map's content now centres on agriculture and trade. This attention leads back to Parrot's agenda which aimed at improving Livland's agriculture and trade on scientific foundations. There is no evidence that Parrot personally encouraged the creation of a new topographic map. But it was he who extensively formulated the aim of the Livonian Charitable and Economic Society, which finally ordered and paid for the creation of the map as a basis for future measures. Parrot was also the one to educate and support students at the University of Dorpat as future public servants, who finally became responsible for the idea and scientific basis of the map. Although Parrot constructed a tangible instrument for the making of the map, his major importance lay in his theoretical contribution. Parrot's Physiocratic and Cameralistic agenda influenced the preconditions for the appearance of the Specialcharte von Livland. In this sense the map serves as the cartographical representation of Parrot's agenda.

\section{References}

Anonymous [Parrot, G. F.] (1795), Über eine mögliche ökonomische Gesellschaft in und für Liefland, Riga: W. C. A. Müller.

[Beise, T.] (1852), Die Kaiserliche Universität Dorpat während der ersten fünfzig Jahre ihres Bestehens und Wirkens: Denkschrift zum Jubelfeste am 12ten und 13ten Dezember 1852, Dorpat: Gedruckt bei J. C. Schünmann's Wittwe und C. Mattiesen.

Blum, K. L. (1838), 'Entwurf eines Schema's zur Statistik Livland's,' in Livländische Jahrbücher der Landwirtschaft, vol. 1, Heft 2, Dorpat: Livlandische ökonomische Gesellschaft, pp. 88-100.

Blum, K. L. (1858), Ein russischer Staatsmann, Des Grafen Jacob Johann Sievers, Denkwürdigkeiten zur Geschichte Russlands, vol. 4, Leipzig \& Heidelberg: C. F. Winter.

Engelhardt, H. D. \& Neuschäffer, H. (1983), Die Livländische Gemeinnützige und Ökonomische Sozietät (1792-1939), Quellen und Studien zur baltischen Geschichte, vol. 5, Köln \& Wien: Böhau Verlag.

Friebe, W. Ch. (1802), Grundsätze einer theoretischen und praktischen Verbesserung der Landwirtschaft in Liefland, vol. 1, Riga: C. J. G. Hartmann. 
Gümbel, W. von (1897), 'Werner, Abraham Gottlob,' in Allgemeine Deutsche Biographie, vol. 42, pp. 33-39.

Hehn, C. (1858), Die Intensität der livländischen Landwirtschaft, Abthl. I., Der Grund und Boden, und die Arbeit, Dorpat: Gedruckt bei J. C. Schünmann's Wittwe und C. Mattiesen.

[Jaquet, F. D.] (1819), Einige Gedanken die Anfertigung eines Atlasses Livlands betreffend, EAA, f 1185, n 1, s 48, National Archives of Estonia, Tartu

Kretschmer, I.; Dörflinger, J. \& Wawrik, F., eds. (1986), Lexikon zur Geschichte der Kartographie, vol. 2, Wien: Franz Deuticke.

Levitskii, G. V., ed. (1902), Biograficheskii slovar professorov i prepodavatelei Imperatorskogo Yurievskago, byvshego Derptskogo, universiteta za sto let ego sushchestvovaniia (1802-1902), Yuriev: K. Mattisen.

Löwis, A. von ([1839?]), Über die Bearbeitung der auf Kosten der Livländischen ökonomischen Societät ausgeführten Specialcharte von Livland, in sechs Blättern [text supplement to the map], EAA, f 1185, n 1, s 595, Sheet 5, National Archives of Estonia, Tartu.

Mellin, L. A. von (1798), Atlas von Liefland oder von den beyden Gouvernementern $u$. Herzogtümern Lief- $u$. Esthland u. der Provinz Oesel, (published in Riga in 1791-1798, in Leipzig in 1808), Riga: bey J. F. Hartknoch.

Numers, G. von (1910), Recapitulation über die Entstehung der C. G. Rückerschen Karte Livlands. Zusammengestellt für die Kaiserlich livändische gemeinnützige und ökonomische Societät, Manuscript, Dorpat, EAA f 1185, n 1, s 595, National Archives of Estonia, Tartu.

Parrot, G. F. (1802), 'Ueber einige Ansichten der Naturkenntnisse, in Ansehung ihres Einflusses auf Menschen-Cultur, sowohl von der intellectuellen, als von der moralischen Seite betrachtet,' in G. B. Jäsche (ed.) Geschichte und Beschreibung der Feyerlichkeiten bey Gelegenheit der am 21 sten und 22 sten April 1802 geschehenen Eröfnung der neu angelegten Kayserlichen Universität zu Dorpat in Livland, Dorpat: M. G. Grenzius.

Parrot, G. F. (1831), 'Description d'un nouveau pantographe,' in Mèmoires de l'Académie impériale des sciences de St.-Petersbourg, Sc. Math., T. I, St.-Petersbourg: Impr. de l'Académie, pp. 25-38.

Rathlef, K. (1852), Skizze der orographischen und hydrographischen Verhältnisse von Liv-, Esth-und Kurland, ein geographischer Versuch, Reval: Kluge \& Ströhm.

Recke, J. F. \& Napiersky, K. E., eds. (1827), Allgemeines Schriftsteller- und Gelehrtenlexikon der Provinzen Livland, Esthland und Kurland, vol. 1, Mitau: Bey J. F. Steffenhagen und Sohn.

Recke, J. F. \& Napiersky, K. E., eds. (1831), Allgemeines Schriftsteller- und Gelehrtenlexikon der Provinzen Livland, Esthland und Kurland, vol. 3, Mitau: Bey J. F. Steffenhagen und Sohn. 
Varep, E. (1957), C. G. Rückeri Liivimaa spetsiaalkaardist 1839. aastal, Tallinn: [Eesti NSV Teaduste Akadeemia].

Martin Jeske is a research fellow at the University of Basel, Switzerland. He studied human geography, cultural sciences and history at the Friedrich Schiller University in Jena, at the European University Viadrina in Frankfurt (Oder), Germany, and at the Pedagogical State University in Barnaul, Russian Federation. Prior to his studies he completed professional training as a surveyor at the mapping agency of the Federal State of Thuringia in Gotha, Germany. 